\title{
Tendencies of Expressionism in Rainis' Writings: Spēlēju, dancoju (I Played, I Danced, 1915)
}

\author{
ZANE ŠILIN̦A
}

\begin{abstract}
The paper focuses upon the specific tendencies of Expressionism in the outstanding Latvian poet and playwright Rainis' (Jānis Pliekšāns, 1865-1929) writings. Rainis always tried to follow the current trends in art, at the same time elaborating his own specific style of expression, therefore his oeuvre is characterized by a peculiar combination of the traditional and modern or, in other words, specifically Latvian elements combined with European modernist features. One of the brightest examples is his play Spēlēju, dancoju (I Played, I Danced, 1915), which is marked by trends akin to Expressionist art, as well as their very specific translation into Latvian tradition. Although Expressionism in its most impressive manifestation appears in German literature, a kindred world vision can be also found in other countries, in some cases even earlier than in Germany. For instance, expressionistic tendencies are characteristic of the literary works of the Russian writer and playwright Leonid Andreyev (1871-1919). Rainis' diaries, letters and notes demonstrate a stable and permanent interest in Expressionism and particularly Andreyev. Although the Latvian poet's attitude to his Russian colleague's literary works mostly can be characterised as negative, Rainis' notes show that in Andreyev's artistic quests he has also found some impulses for his own writings. While exploring the tendencies of Expressionism in Rainis' writings, the paper discusses the specific use of grotesque and the intensified relations between the living and the dead in the play Spèlēju, dancoju. It is significant that the relations between life and death, the living and the dead is one of the central themes in Expressionism, and its relevance is determined by the political events at the beginning of the $20^{\text {th }}$ century (especially, the First World War), as well as the development of industrial society. In order to demonstrate the most significant points of interaction shared by Spēlēju, dancoju and Expressionism, as well as the uniqueness of Rainis' artistic manner, the paper gives an insight into the aesthetics of Expressionism and provides a comparative analysis of Rainis' play and some examples of Expressionist art (e.g., writings by Leonid Andreyev, Georg Kaiser, Ernst Toller).
\end{abstract}

Keywords: Jānis Rainis, Leonid Andreyev, the First World War, Expressionism, grotesque, living, dead

During the years of the First World War essential changes can be identified in the creative works by the outstanding Latvian poet and playwright Rainis (Jānis Pliekšāns, 1865-1929) - he does not only emphasize responsibility of 
ŠILIN̦A

art towards its epoch, foregrounds the need of expressing topical feelings and solving the most significant issues posed by the era but turns also to the search for new stylistic means of expression. Essentially it means a move towards Expressionism. ${ }^{1}$ Although Rainis' attitude to Expressionist art was ambiguous (even more so - the poet mostly addressed harsh criticism to Expressionism), he knew its basic postulates well enough due to his fairly active interest in German contemporary literature ${ }^{2}$, and in literary works by Leonid Andreyev ( АеониА Анареев, 1871-1919), the Russian playwright and prose writer, whose oeuvre is marked by very obvious Expressionist features both in the choice of themes and also in the specific characteristics of his poetics - especially the use of hyperbolization and grotesque (Švecova 1975; Muratova 1983; Grigor'ev 1972; Babičeva 1971; Bugrov 1968). Andreyev's name has been mentioned in Rainis' letters, diaries, notes and drafts of his new works from 1903 till 1913, and these documents give evidence that Rainis knew Andreyev's writings and views on issues of art aesthetics very well; besides creative activity of the Russian author has quite frequently been an object of direct reflection, as well as one of the most favoured examples when commenting on different trends in society and art. It is possible that in Andreyev's works Rainis found a source of direct and implicit impulses also for his own creativity. ${ }^{3}$ In his writings Rainis always tried to follow the current trends in art, at the same time elaborating his own specific style of expression, therefore his oeuvre is characterized by a peculiar combination of the traditional and modern or, in other words, specifically Latvian elements combined with European modernist features. One of the brightest examples is his play Spēejeju, dancoju (I Played, I Danced, 1915), which is marked by trends akin to German and Russian Expressionist art, as well as their very specific translation into Latvian tradition.

Examining Rainis' links with Expressionism, one has to mention another significant aspect. More than any other trend in art, Expressionism is associated not only with a search for new ways and approaches in art but also with the specific political and social background. One can even talk about a special spirit of the epoch characterized by a poignant sense of disharmony in the

\footnotetext{
Some aspects of the First World War as the turning-period in Rainis' writings have been discussed by Benedikts Kalnačs (Kalnačs 2001: 49-60).

2 Rainis' translations of foreign poetry (the poems by Johannes Robert Becher (18911958), Walter Hasenclever (1890-1940), Else Lasker-Schüler (1869-1945), August Stramm (1974-1915), Franz Werfel (1890-1945) and other Expressionists) along with his memoirs Kastanola (Castagnola, 1926; Rainis 1983a), letters and diaries are some of the brightest examples.

3 I have written about the matter in the article Rainis un ekspresionisms (Rainis and Expressionism; Šiliṇa 2005).
} 
world. Horrors of the First World War, sense of hopelessness in the crumbling world, experience of the tragic events of 1905, the life full of uncertainty during emigration in Switzerland and a sense of guilt to the homeland devastated by war could not but influence Rainis' already acute and exalted world perception.

Although the idea of the play Spēlēju, dancoju had been conceived and brewing in the poet's mind for more than ten years, the text of the play was written in an extremely short period of time - approximately from January 4, 1915 till February 27 while Rainis was in emigration in Castagnola, Switzerland (Rainis 1983: 587; Hausmanis 1981; Hausmanis 1973: 193-211). The plot of Spèlejju, dancoju is partially based on the Latvian folklore and partially on the legend of Orpheus and Eurydice. The protagonist of the play Tots is a musician, who has to bring back his beloved girl Lelde (the symbol of Latvia) from the Underworld, where she was brought by the dead Master (Kungs). In order to save Lelde Tots struggles not only with the Master, but also with devils whose habitation - the Devils' threshing barn is interpreted as the world of Chaos. The play reveals the eternal conflict between good and evil, day and night and emphasizes the importance of the mental strength and of arts as the source of this strength.

The poet has repeatedly emphasized that a strong, even decisive impulse for the bulk of the text of Spēejeju, dancoju was the specific political situation the First World War and the shock caused by it. Therefore it is quite logical that much of the play deals with representation of relationship between life and death, the living and the dead. It does not merely in a peculiar way characterizes the nation's historical experience and Rainis' social and political position, but reflects the poet's ethical ideals, outlines the collapse of his dream of future vision and explicitly conveys the poet's emotional state during writing the text. Significantly, the relationship between life and death, the living and the dead is also one of the central themes in Expressionist art and its popularity is determined by the topical political and social events at the beginning of the $20^{\text {th }}$ century, as well as by development of the industrialized society and loss of spirituality in man caused by that.

Triumph of devastation and death in the $20^{\text {th }}$ century has apparently been most harshly manifested and experienced in Expressionist art. Years of the revolutions and the First World War meant a victorious march of death, the horror of physiological disintegration and bodily decay at the beginning of the $20^{\text {th }}$ century was coupled with horrors brought along by the world's technological development, namely, spiritual death, when a human being turned into a worn-out thing in mundane life or a mechanism subjected to the rules of society. Thus one of the most significant Expressionist themes is transformation of a human being into a thing, turning of individual into an 
ŠILIN,A

extension of the machine and succumbing to its luring grandeur. Explicit manifestations of this theme can be identified in Georg Kaiser's (1878-1945) dramatic trilogy Die Koralle (The Coral, 1917), Gas (Gas, 1918) and Gas II (Gas II, 1920), as well as in the play by Andreyev Tsar Golod (Царь Голод, King-Hunger, 1908) in which a human being and machine merge into a monstrous hybrid:

At the rise of the curtain the stage represents the interior of the factory in black and red. The red, the fiery - these are the lights of the furnaces, the incandescent bars of iron over which (diffusing sparks), hammer dark shadows of men. The black, the shapeless, like descending gloom - these are the silhouettes of the monstrous machines, whimsical structures assuming the menacing aspect of a nightmare. Sternly impassive they press with all their might and crush the men with their colossal weight. [...]

And a small black shadows swarm the men below. Eagerness is absent in their movements; there is no ardent, impetuous freedom of gesture. Regularly and automatically they talk and move, in measure with the hammers and working machines; and when some one juts out of the mass, he seems as a piece chipped off the gloomy machine, the odd structure appearing like some obscure monstrosity.

The clatter of the operating hammers and machines now arguments, then abates. And the voices of the men imperceptibly stream into their chorus and sound in unison, now quick and sonorous, then dull, brief, torpid, almost dead. [...

- We are crushed by the machines.

A Shrill Voice. - We ourselves are parts of the machines.

- I am the hammer.

- I am the flapping belt.

- I am the lever.

$[\ldots]$

- We are the machines.

- No. We are food for the machines. ${ }^{4}$ (Andreyev 1911: 405-407)

The factory image characteristic of Expressionist aesthetics can be also seen in Fritz Lang's (1890-1976) film Metropolis (filmed from 1925 till 1926, first screened in 1927).

It is essential that the grotesque portrayal of human body in Expressionist art does not merely represent physical death but also the internal state of the

\footnotetext{
4 Translated by Eugene M. Kayden.
} 
individual - deformity of spirit, emptiness, and peculiar aspirations to death, sometimes decay and degeneration.

Kindred ideas are linked also with grotesque representation of the union between the living and the dead in Rainis' writing. In his foreword to the play Spēlejju, dancoju (the foreword was written in 1925) Rainis emphasizes two aspects significant in the context of the present study. Firstly, Spēlēju, dancoju is a play written with a concrete socially political aim, secondly, Spēejeju, dancoju presents a synthesis of the tragic and the comic, and this is one of the preconditions of the grotesque. (Rainis 1983: 588-589)

The above mentioned aspects can be clearly identified in the Master's (Kungs) image. The Master according to Rainis' interpretation is a German baron-vampire. This image combines the living and the dead, because the Master lies in the coffin without decay, he is still capable of rising from the dead to inflict harm to cattle and people. ${ }^{5}$ It is significant that similar images representing death are characteristic for Expressionist art. The brightest examples can be found in Expressionist cinema - Friedrich Murnau's (1888-1931) famous vampire Nosferatu in Nosferatu, eine Symphonie des Grauens (Nosferatu: A Symphony of Horror, 1922), Robert Wiene's (1873-1938) priest of death and madness Kaligari and the somnambulistic murderer Cezare in Das Cabinet des Dr. Caligari (The Cabinet of Dr. Caligari, 1920), Paul Wegener's (1874-1948) Golem in Der Golem (The Golem, 1920) as well as Death in Fritz Lang's film Der Müde Tod (Weary Death, 1921). Shattering images representing death are created also by fine arts. ${ }^{6}$

Returning to Rainis' Spēlēju, dancoju it must be noted that the outer appearance of the Master foregrounds such attributes that are clearly associated

5 „Nakšu naktis apkārt lied,

Lopus jāj, asins sūc, -

$[\ldots]$

Miris? - Guḷ kā gluži dzīvs,

Ozolzārkā nesapuvis -

$[\ldots]$

Sūkdams mūs, valda vēl,

Tā kā valdīijis kopš laika." (Rainis 1981: 275)

Unfortunately, the play is not translated, therefore the quotations of Rainis' verse text (which is quite specific) will be given only in footnotes.

6 One of the most impressive examples is Käthe Kollwitz's (1867-1945) woodcut print Die Freiwilligen (The volunteers) from the portfolio Krieg (The War, 1921-1922, published in 1923). The print represents death figure leading off a troop of solders, one of whom is Kollwitz's own son, who volunteered to serve in the First World War at the very beginning, and was killed in action two months later. (Kollwitz 1923) 
ŠILIN̦A

with death and decay. Thus, for example, before going to the Devil's barn the Master orders the Devil's boy to "spruce him up" in a peculiar way - to sprinkle him with dust, to decorate his brows with leeches, to put round his neck a snake instead of a necktie and so on ${ }^{7}$. These appalling accessories are in dissonance with the comic effect created by the Master's behaviour - he is boasting with his class superiority, the Mater's dust is more lavishly dusty, the bones are rattling more drily and his stench stinks more fiercely than of the dead of lower social status ${ }^{8}$, he guards from potential thieves the splendid decorations of burial (the silver rim and nails of the coffin), he boasts arrogantly of his special skills to inflict harm to people", yet being German he is afraid of the "low-lives" (Latvian peasants) pagan spirits and deities ${ }^{10}$.

The dead Master's movements have also been duly described - they are stiff, sharp and lifeless"1, when the Master claps his hands they "sound like wood" (Rainis 1981: 332), thus creating a frightening mood. Yet at the same time he is granted also the functions of a live body and the biological features linked with them which sometimes provide a comic tonality. For example, when sucking blood, the Master has to observe moderation because of his weak stomach and quick spells of dizziness. ${ }^{12}$

7 „Ūsās ieberz raganvēmas!

Svārkiem uzber bijas pī̌ş̧us!

Pagrāb tur tos senču trūdus!

$[\ldots]$

Uzacīs liec dēles!

Mēles sliekas mutē sadzen!

Kaklautiņā apliec čūsku!” (Rainis 1981: 334)

8 „Man, lūk, acīs ķirmju galvas,

Tās tik skaisti, melni dzirkst!

Nu, bet es jau esmu kungs!” (Rainis 1981: 330)

9 „Jā, es velns! Vēl vairāk esmu!

Kā es rauju, tirdu, zīžu [...]” (Rainis 1981: 327)

10 „Nē jel, jupi nepiemini!

Lādi: belcebuls vai sātans, -

Jupis pagāns, tā man bail! (Rainis 1981: 328)

11 Neliec cel̦us, neliec rokas!

Stāvu gaisā saslienas! (Rainis 1981: 324)

12 „Es būt' vēl to meitu sūcis,

Vājš man vēders, vairāk nenes,

Pilnā māgā grūta guḷa:

Galva reiba triju lāsu

Tā kā triju mucu vīna." (Rainis 1981:328) 
The Master's image is connected with some more particularly characteristic episodes. While lying in the coffin his leg vertebra drops off but the Devil's boy later puts it back; Tots with a crow-bar smashes the Master's hand in splinters but, ordered by the Master, the Devil's boy pours them into his shirtsleeve, thus rearranging "the messed up bones"; devils pull out a vein from the Master for Tots to have the necessary string but later on the vein is replaced by the coffin rim and so on.

Thus the Master in Spèlēju, dancoju is a grotesque image. It combines in itself both the eerie and the funny and resembles a deformed doll that can either fall into bits and pieces and then be mechanically reassembled again. Besides it is important that in the image of the Master Rainis emphasizes not only the vampire's high social status and macabre functions but also his affiliation to past. The Master "is tall and fat, in long and lavish coat made of black velvet, with white socks reaching his knees, a white wig like in the $18^{\text {th }}$ century, a bone hoop round his head with twelve teeth resembling a crown." ${ }^{13}$ (Rainis 1981: 324)

The grotesque rejuvenation procedures of the Master in the house of bones and the devil's barn in a peculiar way represent the harsh reality - succumbing of the people to the hypnotic powers of the past that facilitates periodic rebirth of these shadows in the world of the living. With the help of the Master's image and the play on the whole, Rainis tries to liberate the nation from this dangerous appeal.

It must be noted here once more that unlike Expressionists (Georg Kaiser, Ernst Toller (1893-1939), Leonid Andreyev), whose plays are clearly dominated by tragic pathos and terrifying grotesque, namely, death gains upper hand over life, - Rainis' Spèlēju, dancoju quite extensively uses also the possibilities offered by the comic, and it develops the idea about the liberating and creative powers of the comic. This is also proved by an entry in Rainis' diary on August 18, 1911: "One can laugh about serious things. It does not denigrate but elevates. The serious and the heavy become light and can be lifted. Laughter shows that you grasp the laughter's object in your hand, it is embraced also spiritually. Laughter is a sign of the spirit's victory over matter. Laughter is a winner." (Rainis 1986: 376) Thus it has been extremely important for the poet not only to write about the calamities experienced in the past but also to point out the necessity to overcome the shadows of the past - and more so not by giving them to oblivion or light-mindedly ignoring their impact but by "spiritually embracing them and clasping them in one's hand".

13 Here and further Rainis' prose texts quoted in the article are translated by Viktors Freibergs. 
ŠILIN̦A

At the end of Act 2 of the play the superiority of the Master is degraded because in order to get sooner to the expected entertainment - music and dancing at the devil's party - Master and Devil's boy lift Tots on their shoulders and with sweat on their forehead carry him to the Devil's barn. It is interesting that initially Rainis had intended to emphasize in this episode another sarcastic detail and this is proved also by his excerpt of a text of the would-be play dating back to January 29, 1915: "Master, I will carry you to the coffin, you are newly dead, clumsy. I brought benefits (German culture and capitalism have also given benefits)." (Rainis 1984: 314) Writing this note, Rainis did not associate the Master only with feudalism but also capitalism - which means suppression of people and exploitation in much wider sense of the word.

It is important to emphasize in this context another essential detail which in Rainis' play is different from the trends characteristic of Expressionistic drama. The idea of revolution and rebellion in Expressionist literature in most cases is not aimed at an enemy embodied in an image of one person. Walter H. Sokel also indicates it in his study of Expressionism: "Its enemies are institutions - the state, capitalism, military system, war, but it does not hate people who embody these institutions or acquire wealth from them. They are victims as well, and Expressionists convey pity for them." (Sokel 1977: 183) For Rainis' play Spèlēju, dancoju such pity is not characteristic. Neither the text of Spèlejju, dancoju, or the conveyed thoughts allow the slightest possibilities to interpret the Master as any kind of victim of social mechanism. Unlike, for example, Georg Kaiser or Ernst Toller, who in their interpretation of the social and political situation of the beginning of the 20th century tend to reach a very high degree of generalization and to approach the generally humane, Rainis in the play Spèlēju, dancoju talks specifically about his own nation and his nation's bitter historical experience, leaving for the generalization the human creative spirit embodied in the image of Tots.

Another significant feature distinguishes the way the grotesque combination of the living and the dead is presented in Expressionist art and in the play by Rainis Spèlèju, dancoju. One of the main objects of interest of Expressionists despite the generally human ideas manifested in their work - is the urbanized environment and a factory as one of its most specific attributes. Therefore it is only to be expected that Expressionist art pays attention also to the peculiar industrialization of people - parts of human body when individual dies spiritually-are transformed into parts of machinerygoverning the relationships in the world. While Rainis grants importance to the peasants' sense of life accumulated over centuries, as well as the heavy burden of historical heritage, to be more precise, the specific experience of feudal epoch. 
Thus, if Expressionist drama combines into one eerie image a human being and a machine, human being and a factory, then Rainis in Act 3 of his play Spè èju, dancoju in the Devil's barn scene introduces terrifyingly grotesque images, combining human skeleton and a flail, which in this case not so much signifies peasants' tool of work but rather functions as an attribute of the hard feudal toil. The scene of threshing in the barn is made particularly macabre and emotionally harsh by the fact that the remains of the dead are not only the material of this torment but also its instrument - devils do not merely thresh the bodies and bones of the dead but thresh them with these bones, besides, the visual effect is supplemented by the sound pattern of the text adapted to the threshing rhythm. ${ }^{14}$ Analyzing relationship between life and death, the living and the dead in Rainis' play Spèlēju, dancoju one must also mention the motif of the dance which is one of the most important leitmotifs in the play Spèleju, dancoju. Rainis has used it in a variety of ways but for the context of the given article the dance at the climax of Act 1 is particularly significant when the dead Master dances with Lelde and during the dance sucks the three fateful drops of blood. (Rainis 1981: 290) Although the variations of dancing in the play are possibly connected with impulses rooted in folk tradition, the Master's and Lelde's dance can also be interpreted as a peculiar modification of "Danse Macabre" (the Dance of Death), besides it should be noted that the motif of "Danse Macabre", so peculiar to the Late Medieval culture (e.g., Huizinga 1999: 124-135), in the $20^{\text {th }}$ century art is re-introduced exactly by Expressionism. Explicit examples are the dancing Death sculpture in Fritz Lang's Metropolis, death can-can in Andreyev's play Tsar Golod or also separate episodes from Ernst Toller's plays Masse Mensch (Masses Man, 1921) and Die

14 "VELNU BALSIS

MIRON̦U ATBALSIS

Spriguḷkāts - stilba kauls,

Sprigul̦vāle - liela kauls,

Sprigul̦saite - rokas dzīsla:

Kul, kul, kul!

Kuli, kuli, kul!

VELNU BALSIS

Vai! vai! vai!

Lieli graudi - sirdis,

Mazi graudi - acis,

Sīki ašķi-zobi:

Bir, bir, bir.

Put pelavas - asarmigla,

Put, puti, put!" (Rainis 1981: 359-360) 
ŠILIN̦A

Wandlung (Transfiguration, 1919). It is essential that Expressionism does not interpret dancing Death as fatal and invincible force but as extinction brought about by specific political and social causes (war, industrialized society) and for which consequently man is responsible. Such a trend can be also observed in Rainis' play Spēlēju, dancoju in which the Master's and Lelde's dance introduces the theme of the devastating and destructive past expanded later in the play.

Yet Rainis, as well as Expressionists do not only interpret destruction of man in a peculiar way but also show resurrection of the dead. For example, Leonid Andreyev in the final scene of the play Tsar Golod shows a desolate open space lit by blood-red light of the sunset in which an old cannon is raised on large wheels while corpses of the rebellions - the Famished - are lying in front of it. There are also two of the play's symbolic images here - Death and King-Hunger, as well as the Victors, representatives of the well-off classes of society who, prompted by different feelings, have come to look at the field of the dead, as well as the cannon and now chat among themselves.

Suddenly a confused commotion rises on the dead field, a rustling, an indistinct crunching of broken bones, a persistent scratching of the earth with sharp, dead nails; and terrified, with outstretched necks, the Victors listen attentively. A dull, far-distant, thousand-strong murmur, as if underground, sends a reply.

- We shall yet come. We shall yet come. Woe unto the victorious. ${ }^{15}$ (Andreyev 1911: 458)

The Victors, overtaken by panic of horror, run away. The play ends with KingHunger shouting in a mad joy: "Run! Run! The dead arise!"16 (Andreyev 1911: 459)

One of the most expressive scenes of rising of the dead in the play Spè ēju, dancoju is the cemetery scene in Act 2. Its setting was described by Rainis as follows: "An ancient cemetery. Old graves and crosses, tall trees; everything is overgrown by bushes and creepers. There are some graves in the foreground, like knolls. It is quite dark. Later the moon comes out, dark red." (Rainis 1981, 301) Later on the poet added some more visual effects - glistening sand, small sparkles of light hopping on graves and bushes, light dust rising from graves and paths moves towards Tots and then rising up and - finally - revealing in

\footnotetext{
15 Translated by Eugene M. Kayden.

16 Translated by Eugene M. Kayden.
} 
their bright light a shattering battle-field that gradually gets transformed into a vision akin to Expressionistic art: "Arms and legs emerge from graves towards him; torn and scattered limbs appear on the road in a dim light." (Rainis 1981: 319) Then "like shadows all kinds of black birds fly towards him" (Rainis 1981: 319), "when he moves on, indistinct shadows with white sheets spread in front of him" (Rainis 1981: 319), then "flowers on long stalks shoot out from the ground swinging towards Tots" (Rainis 1981: 319). Finally "a dead man runs out of the grave-yard and dashes past, then several other graves start opening; the dead push out their heads; moaning starts" (Rainis 1981: 320).

Although Rainis seemingly writes about an ancient grave-yard, appearance in it of the torn and scattered limbs makes one think not so much about the suffering endured by the nation during seven centuries of suppression but rather about the horrifying reality of World War I, whose blood-stained presence is made more emphatic by the image of the dark red moon in the sky. Thus Rainis' imaginary graveyard is not so much ancient as touched by oblivion. Yet it is not a sheltering eternal peace but desolation that in Rainis' understanding is unforgivable and tragic, because not only the people and fighters of the old days have been given into the hands of its power but also those who have perished quite recently. The more so, that those resting is this grave-yard have no peace.

In conclusion, it must be noted that Rainis and the Expressionists are united also by the theme of looking for the new - the Future man. Walter H. Sokel writes that Expressionism aspires to create a human being that would combine Prometheus and Christ (Sokel 1977: 172), namely, a new type of a leader who would be a synthesis of the rebellious and creative principle, as well as a messiah capable of sacrificing oneself for the sake of others. It must be admitted that in Rainis' writing, like in Expressionist art, the idea of spiritual activity is closely linked to the need of living in accordance with the highest ethical values and the protagonist of Spēlēju, dancoju Tots is here a very obvious example.

\author{
Zane Šiliṇa \\ zane.silina@lka.edu.lv \\ Latvijas Kultūras akadēmija \\ Ludzas iela 24 \\ LV-1003 Rìga \\ LATVIJA
}


ŠILINA

\section{Bibliography}

Andreyev, L. 1911. King-Hunger. Boston: Poetlore, 1911. - http://babel.hathitrust. org $/ \mathrm{cgi} / \mathrm{pt}$ ?id=mdp.39015030852423;view=1up;seq=8 (07.01.2015.)

Andreev, L. 1991. P'esy. Moskva: Sovetskij pisatel'. = Анареев, К. 1991. Пьесы, Москва: Советский писатель.

Babičeva, J. 1971. Dramaturgija L. N. Andreeva èpohi pervoj russkoj revoljucii. Vologda: Vologdskij GPI. = Бабичева, Ю. 1971. Араматургия А. Н. Андреева эпохи первой русской революиии. ВологАа: Вологаский ГПИ.

Bugrov, B. 1968. Na putjah otrycanija realizma (“Žizn’ čeloveka” i “Car'-Golod” L. Andreeva). - Russkaja literatura XX veka. (Dooktjabrskij period). Kaluga: Tul'skij GPI im. L. N. Tolstogo, 266-288. = Бугров, Б. 1968. На путях отрыцания реализма (“Жизнь человека" и “Царь-Голод” $\Lambda$. Андреева). - Русская митература XХ века. (Аооктлбрский период). Какуга: Тумьский ГПИ им. $\Lambda$. Н. Толстого, 266-288.

Grigor'ev, A. 1972. Leonid Andreev v mirovom literaturnom processe. - Russkaja literatura, 3, 190-205. = Григорьев, А. 1972. АеониА Анареев в мировом митературном процессе. - Русскал митература, 3, 190-205.

Hausmanis, V. 1973. Raiņa dramaturğija. Rìga: Zinātne.

Hausmanis, V. 1981. Spēlēju, dancoju: Sacerēšanas gaita. - J. Rainis, Kopoti raksti 30 sējumos, 11. Rīga: Zinātne, 506-511.

Huizinga, J. 1999. The Waning of the Middle Ages. Mineola, New York: Dover Publications.

Kaiser, G. (Kaizer, G.). 1923. Dramy. Moskva-Petrograd: Gosizdat. = Кайзер, Г. 1923. Арамы. Москва- ПетрограА: ГосизАат.

Kalnačs, B. 2001. Poētikas laikmetīgums Raiṇa lugās "Spēlēju, dancoju” un "Daugava”. - G. Grīnuma, ed., Rainis radošo meklējumu spogulī: Literatūrzinātnisku rakstu krājums, Rīga: Zinātne, 49-60.

Kollwitz, K. 1923. The Volunteers (Die Freiwilligen) (plate 2) from War (Krieg). Moma: The Collection. - http://www.moma.org/collection/browse_results. php?object_id=69683 (07.01.2015).

Muratova, K. 1983. L. Andreev v polemike s Gor'kim (Otnošenie k Mysli). - Tvorčestvo Leonida Andreeva: Issledovanija i materialy. Kursk: Kurskij GPI, 3-12. = Муратова, К. 1983. А. Андреев в полемике с Горьким (Отношение к Мыски). - Творчество Аеонида Андреева: Исследования и материалы. Курск: Курский ГПИ, 3-12.

Rainis, J. 1981. Spēlēju, dancoju. - J. Rainis, Kopoti raksti 30 sējumos, 11. Rīga: Zinātne, 269-478.

Rainis, J. 1983a. Kastaņola. - J. Rainis, Kopoti raksti 30 sējumos, 17. Rīga: Zinātne, 1983, 5-140.

Rainis, J . 1983b. Priekšvārds “Spēlēju, dancoju”. - J. Rainis, Kopoti raksti 30 sējumos, 18. Rìga: Zinātne, 587-590.

Rainis, J. 1986. Dienasgrāmata. 18.8.11. [18.08.1911.] - J. Rainis, Kopoti raksti 30 sējumos, 24. Rīga: Zinātne, 376. 
Tendencies of Expressionism in Rainis' Writings

Švecova, L. 1975. Tvorčeskie principy i vzgljady, blizkie k èkspressionizmu. - B. Bjalik, otv. red., Literaturno-èstetičeskie koncepcii v Roscii konca XIX-načala XX v. Moskva: Nauka, 252-255. = Швецова, А. 1975. Творческие принципы и взгляАы, близкие к экспрессионизму. - Б. Бямик, отв. реА., Аитературноэстетические концепции в России конца XIX- начала XX в. Москва: Наука, $252-255$.

Šiliņa, Z. 2005. Rainis un ekspresionisms. - Letonica, 12, 37-47.

Sokel, W.H.1977. The Writer in Extremis: Expressionism in Twentieth-Century German Literature. Stanford, California: Stanford University Press.

Toller, E. 1919. Die Wandlung: Das Ringen Eines Menschen. Potsdam: Gustav Kiepenheuer Verlag.

Toller, E. 2003. Masses and Man. - E. Schürer, ed., German Expressionist Plays. New York: Continuum, 198-242. 